\title{
LISTING BRICs: \\ STOCK ISSUERS FROM BRAZIL, RUSSIA, INDIA AND CHINA \\ IN NEW YORK, LONDON, AND LUXEMBOURG
}

\author{
Working Paper in Employment, Work and Finance 09-12
}

\section{Dariusz Wójcik* and Csaba Burger}

School of Geography \& the Environment and St.Peter's College, Oxford University

South Parks Road, OX1 3QY, Oxford, United Kingdom

dariusz.wojcik@spc.ox.ac.uk (corresponding author)

csaba.burger@ouce.ox.ac.uk

\begin{abstract}
In the last decade hundreds of companies from emerging markets have listed and issued their shares on American and European stock markets. Brazil, Russia, India, and China have been the main origins of issuers, and stock exchanges in the US, UK, and Luxembourg the main destinations involved in the process. These four home and three host markets are the empirical focus of our paper. We present an economic geography perspective on foreign listing, grounded in the geography of finance and the world city network approaches, emphasising the sub-national origins of foreign listed firms, the role of intermediaries, and competition for foreign listings. Our analysis, based on comprehensive up-todate datasets on foreign listings and foreign equity issues, shows that issuers listing their shares abroad are predominantly large firms, coming from relatively high-growth, internationally oriented sectors, and headquartered overwhelmingly in the leading economic centres of their home countries. Key intermediaries in the foreign listing process are the global investment banks, operating out of the very same centres where the cross-listing firms and the host stock exchanges are located. Competition between host stock markets is affected significantly by the direct and indirect costs of foreign listing, including disclosure and corporate governance requirements. Both host markets and intermediaries exhibit a significant degree of specialisation in terms of the size, sector, and geographical origin of the issuers they serve. The market for foreign listing differs significantly between the BRIC countries, with the Chinese market offering the greatest potential, but facing considerable uncertainty.
\end{abstract}

Key words: foreign listing, stock markets, geography of finance, world city network, emerging markets

JEL categories: F2, G15, G24 


\section{Introduction}

Foreign listing, referred to as the listing and trading of corporate shares on stock markets outside of the home country of the issuer, has a long history. In late $19^{\text {th }}$ early $20^{\text {th }}$ century there were already hundreds of foreign stocks traded on the London Stock Exchange and the Paris Bourse (Cassis 2006). After the Second World War, foreign listing, along with most types of international financial flows, was curtailed. It awoke like most international financial activity in the 1980s and took off in the 1990s. Out of 3,683 foreign listings at the end of 2006, approx. 85\% took place after 1980, and 65\% after 1990 (Sarkissian \& Schill 2009). Between 2005 and 2007 alone above \$130bn of new capital was raised globally through depositary receipts, the dominant mode of foreign listing (BNYM 2008). Although investors are now able to buy and trade stocks of foreign issuers directly in the domestic markets of these issuers, foreign listing remains important. Research shows that in the US for example, investors strongly prefer holding and trading foreign shares listed in the US to shares bought directly in foreign markets (Karolyi 2006).

Foreign listing market, like primary equity market in general, is cyclical. It is popular when stock prices grow, but can come to a standstill when they fall, as has been the case since the middle of 2008. Interestingly, historical waves of foreign listing are much more similar in terms of destinations (host stock markets) than in terms of origins (countries where foreign listing issuers are headquartered). The US and the UK have been the top host markets since the 1960s, and their share in the total number of foreign listings in 2006 was approx. $60 \%$. Luxembourg claimed the third place, although far behind the top two destinations (Sarkissian \& Schill 2009). The geography of foreign listings in terms of their origins, however, has witnessed a major shift. While until late 1990s issuers entering foreign stock markets would come mostly from Europe, North America, and Australia, the 2000s saw a boom in foreign listings from emerging markets, with their rapidly developing corporate sectors demanding external capital. The four largest emerging market economies of Brazil, Russia, India, and China in 2007 accounted for $73 \%$ of new depositary receipts listed on foreign stock exchanges, $63 \%$ of capital raised, and $48 \%$ of trading value (BNYM 2007). At the end of 2008 the share of the four countries in the total number of outstanding foreign listings reached approximately $20 \%$.

While the global pursuit of stock issuers from emerging markets has been well covered by media and consultancy reports (e.g. Research Republic 2008), it has received little attention in social sciences beyond financial economics. The latter, however, has thus far focused on studying foreign listings as relationships between home and host countries, with little interest in whether and where foreign listing activity is concentrated within home and host countries. While Fernandes and Giannetti $(2009,1)$ note that "countries whose exchanges manage to attract more foreign listings are likely to be the winners of the competitive struggle to become (or remain) major financial centres of the global economy" there is no research applying a sub-national scale of analysis to foreign listing. In addition, little attention is given to the agency of stock exchanges competing for foreign listings, not to mention other intermediaries, such as investment banks. Finally, given the significance of foreign listings in shaping the future map of 
financial decision-making centres of the world, it is striking that the political nature of foreign listing has hardly been studied.

The objective of this paper is to present an economic geography perspective on foreign listing, by focusing on companies from Brazil, Russia, India, and China listing their shares on the stock markets in the US, UK, and Luxembourg. These four home and three host countries represent the most dynamic part of the market for foreign listings. In addition, focus on a limited number of countries allows us to study foreign listing beyond country-to-country relations, specifically to investigate the sub-national geography of foreign listing, the role of intermediaries, and political factors. The following questions are addressed:

- Who are the foreign listed firms and where do they come from?

- Who are the firms that connect issuers to foreign stock markets and what role do they play?

- How do different actors in host markets, and stock exchanges in particular, compete for foreign listings?

- What is the relative importance of countries, sectors and cities in the geography of foreign listings?

Our theoretical approach to foreign listing is based on a combination of two existing approaches within economic geography: the geography of finance (Clark \& Wójcik 2007), and the world city network (Taylor 2004), presented in section 2. The following section describes data used in the paper. Sections 4 through to 7 document and account for the different aspects of the geography of foreign listing, starting with the national and sub-national origins of foreign listed firms, through the intermediaries involved in the process, and finishing with their destinations in terms of countries and stock markets. Section 8 concludes, and draws some implications for economic geography and further research.

\section{Economic geography of foreign listing}

To develop an economic geography approach to foreign listing, we first need to understand why firms list their shares abroad. In an integrated frictionless global capital market investors would have no regard for the country of origin of stocks or the location of their trading venue. Issuers' choice of where to list their shares would have no effect on their pool of investors. In reality, trading shares listed on foreign stock exchanges is still more costly than dealing with stocks listed domestically, not least because of the complexities of cross-border clearing and settlement. Information relevant to share price of foreign issuers is often available only in a foreign language, and even if translated, making sense of it requires understanding foreign laws and customs. In addition, institutional investors in many jurisdictions still face restrictions on the share of their portfolio that can be invested in shares traded on non-US exchanges. In these conditions, listing shares abroad makes shares more accessible to investors in the host market, and overcomes international stock market segmentation (Karolyi 2006). 
The conventional wisdom explaining foreign listings with stock market segmentation, dominant in the 1990s, has been challenged in the last decade by the view that foreign listing gives firms an opportunity to change their corporate governance (Stulz 1999). Given that by listing abroad, a firm enters the legal and regulatory environment of the host market, firm's insiders (managers and/or large, controlling shareholders) can 'bond' themselves to a legal system with more effective protection of minority shareholders. A host market may also require a more stringent disclosure of information relevant to investors, both at the time of foreign listing and afterwards. Beyond laws and regulations, foreign listing may expose a firm to a market for corporate control, whereby it can be taken over if management underperforms. Finally, foreign listed firms may become subject to the scrutiny by information and reputation intermediaries such as analysts and investment banks that have more expertise than institutions present in the firm's home market. All these factors should make a company friendlier to minority shareholders, increase its share price, and effectively the amount of capital a company can raise for a given portion of its equity. In support of the 'bonding' theory, it has been shown that non-US firms listing in the US attain significantly higher prices than their counterparts without a US listing (Doidge et al. 2004). 'Bonding' may also explain why the US and the UK stock markets, known to have the most minority shareholder friendly corporate governance regimes, have attracted an overwhelming and growing portion of all foreign listings in the world. As corporate governance around the world has become more shareholder-friendly in the 1990s and the 2000s, few countries other than the US and the UK can offer additional 'bonding' services (Wójcik 2006, Fernandes \& Giannetti 2009).

While access to foreign investors and 'bonding' may explain why firms list abroad, research in financial economics also tries to explain how firms choose foreign listing venues, and how they time their listing. Sarkissian and Schill (2004) demonstrate that proximity between the host and home market play a crucial part in choosing the foreign listing venue. Different forms of proximity are important: distance, foreign trade links between the host and home country, language and colonial links, as well as similarity in terms of industrial structure. In other words, while foreign listing is about entering new capital markets, firms tend to be attracted to host markets that are already familiar with them, or those that are more likely to become familiar. Recent research has also investigated the unequal distribution of foreign listings over time. Foreign listings occur in waves, with companies trying to capitalise on favourable conditions in host markets (Sarkissian \& Schill 2009, Fernandes \& Giannetti 2009). In the 1980s for example, a booming stock market attracted many foreign companies to list in Japan. In the 1990s the Internet boom in the US attracted hundreds of foreign firms, particularly high-technology firms to list in the US and NASDAQ in particular (Pagano et al. 2002).

There is a growing body of research focusing on foreign listings from emerging markets. Firms from such markets should have more incentives to seek foreign listings than those from more developed capital markets. Emerging stock markets tend to have higher transaction costs and poorer disclosure practices. Listing on foreign markets presents firms from emerging markets with multiple opportunities: lower transaction costs for investors, more informative financial 
reporting, more accurate analyst forecasts, and ultimately better access to capital (Edison and Warnock 2008). Indeed, it has been shown that the valuation premium for foreign listing firms is particularly high for firms from emerging markets (Doidge et al. 2004). While the advantages to foreign listed firms seem clear, the impact of foreign listing on domestic firms that do not foreign list, and domestic stock markets in general are subject to a debate. First, the domestic market can suffer from a 'migration effect'- as some trading moves abroad, the liquidity of the domestic market falls and the costs of trading (some of which, e.g. that of clearing and settlement infrastructure, are fixed) per trade increase (Levine et al. 2007). Another effect is the 'diversion effect', whereby domestic investors consider domestic firms that do not foreign list as 'losers' and switch their investment to foreign listed stocks.

Some however argue that foreign listing may have positive impacts on domestic stock markets. According to Fernandes (2009), foreign listing may make foreign investors buy shares of companies that have returns highly correlated with those of the foreign listed firms. Foreign investors may also perceive foreign listing as a market liberalisation event, improving their evaluation of the whole domestic market. In addition, Chandar et al. (2009) suggest that the share prices of foreign listing firms react less negatively during currency crises than their non-foreign listing counterparts, thus cushioning the impact of the crises on domestic capital markets. The impact of foreign listings depends also on the reaction of the home market of foreign listing firms. On the one hand, it may put pressure on domestic intermediaries to compete with foreign markets, and on domestic regulatory authorities to make capital market more shareholder-friendly (Karolyi 2004). In 1996 the Johannesburg Stock Exchange moved from floor to computer trading, partly due to the migration of issuers to London (Michie 2006). On the other hand, foreign listing may erode trading and issuance on the domestic market so much, that incentives for local intermediaries to innovate are reduced (Moel et al. 2001). Empirical results are mixed.

Although current research, conducted mostly within financial economics, considers the role of institutional diversity and geographical proximity, it should still be deemed unsatisfactory from an economic geographical perspective. Its major weakness is that it treats foreign listing as a world of relations between countries. Methodologically, a typical project uses data on home country characteristics, host country characteristics, geographical proximity between pairs of countries, and financial firm-level characteristics. There are three important omissions. First, the sub-national level of analysis is ignored. Little is known about particular cities and regions foreign listing firms come from. Second, there is silence on the agency of intermediaries acting on the foreign listing market. There is some interest in stock exchanges competing for foreign listings, but who are the institutions that assist on issuer's way to foreign markets? Third, the political factors affecting foreign listing are overlooked. This paper attempts to further our understanding of foreign listings, by applying a combination of the geography of finance and the world city network approaches.

The geography of finance is a field of enquiry within a large body of geographer's work on finance, which focuses on the threats and opportunities international financial markets, with institutional investors in the lead, present to firms, as 
well as firms' responses to these threats and opportunities (Clark \& Wójcik 2007). The main source of impact is stock market valuation of firms, whereby stock markets, for better or worse, put a price on the perceived virtues and vices of whole countries, regions, sectors and individual firms, forcing them to adjust or risk withdrawal from the stock market. What is important, the response to these pressures does not have to happen at the level of the nation state. In the light of this, by foreign listing firms may be seen as by-passing national institutions. In addition, the geography of finance suggests that the stock market driven behaviour of firms will have systematic effects on cities, regions, and sectors in which these firms operate, as the stock market pressures on large listed firms may trickle down to their non-listed suppliers, customers, and other related firms.

The world city network approach, grounded in urban studies sees the formation of the world city network (WCN) as a key spatial expression of economic development. The WCN consists of three layers: the net level of the global economy with all flows it consists of, the node level of cities, and the sub-nodal level of service firms. The latter, and advanced producer services such as finance and law firms in particular, are seen as the primary agents of network formation (Taylor 2004). While the concentration of foreign listing activity in New York and London has been noticed in the literature on global cities, from which the WCN approach draws inspiration, it has not however been studied in any depth (Sassen 2001). This is surprising, since many features make foreign listing an ideal object of study from the WCN perspective. To start with, foreign listing by nature represents a link between the city an issuer is headquartered in and the foreign city with an exchange on which it lists its shares. Second, foreign listing offers an opportunity to analyse the role of service firms that 'bring' issuers from home markets to host markets. Indeed, studying foreign listings can contribute to urban studies in general. Moving from the study of national urban systems, via the world city hypothesis of Friedman to Sassen's global city and Taylor's WCN, the attention in urban research has shifted away from cities as decision-making centres of manufacturing firms to cities as centres of financial and other advanced business services. Firms listing shares abroad can come from all economic sectors. Thus, an empirical study of foreign listings does not discriminate against firms that are not advanced business services; it addresses the very connection between the latter and their customers.

The geography of finance and the WCN complement each other with regard to foreign listing. The former helps the WCN to conceptualise the net level of the global economy relevant to foreign listing, in particular stock market structure and flows, including the role corporate governance and regulatory regimes. The contribution of the WCN is the focus on the role of service firms in foreign listing activities, and on the significance of cities and their networks in the footprint of these activities. By focusing on urban scale, we do not however exclude national and sectoral scales of analysis. The urban scale can only be appreciated in relation to other scales.

\section{Data}


Before we present data on foreign listings, we must clarify our definition of foreign listing. In the simplest terms, it refers to the listing of corporate shares on a stock market outside of the home country of the issuer (the country where the issuing company is headquartered). To be sure, there are different levels of listing, ranging from quotation of stocks on a foreign over-the-counter market accessible only to institutional investors, to listing on a foreign stock exchange, accessible to the public, with extensive requirements for the issuer to comply with reporting and corporate governance requirements of the host market. Thus, the nature of foreign listing depends not only on the host country but also on the specific segment of the stock market.

Foreign listing is often referred to as cross-listing, implying that a company is listed on its domestic market before listing abroad, which is not always the case. In fact, the term most commonly used with regard to foreign listing is depositary receipts, as the latter are the dominant vehicle of foreign listing. Depositary receipts (DRs) are financial instruments, which represent equity (ownership rights) in a foreign company, but are denominated in the currency of the host market, and can be bought and sold just like domestic stocks, following the same clearing and settlement procedures. Their objective is to make investment in foreign shares as easy and convenient as in domestic shares. In a sense, they convert foreign shares into domestic shares. DRs can be exchanged at any time for the actual foreign shares, which ensures the link between the price in the domestic and foreign market. There are different types of DRs. The best known are the American Depositary Receipts (ADRs) traded over-the-counter or on the US exchanges, and Global Depositary Receipts (GDRs), which combine an ADR with a DR in Europe. Other countries, including Belgium, Netherlands, Sweden and Singapore also have local DR schemes, but on an incomparably smaller scale. As an alternative to DRs, some stock exchanges allow foreign issuers to list directly (JP Morgan 2009).

The objective of our data collection was to cover all foreign stock issuers from Brazil, Russia, India, and China (BRIC) present on the stock markets of the US, UK, and Luxembourg. Review of existing research and trade reports assures us that there are few companies from the BRIC countries that have foreign listings outside of the three host markets. Singapore hosts a number of Chinese issuers, but does not as yet threaten even Luxembourg's position as market for firms from the BRIC states. While we acknowledge that Hong Kong could be treated as a foreign listing location for Mainland Chinese firms, data on these foreign listings is less readily available than that for the US, UK, and Luxembourg markets. We treat Hong Kong as a part of China, and Hong Kong companies listing abroad as a subset of Chinese foreign listings.

We have created a dataset on issuers from the BRIC countries listing in the US, UK, and Luxembourg. Data on listings in the US and Luxembourg was derived from the database on depositary receipts from the Bank of New York Mellon (BNYM). To the best of our knowledge, there are no issuers from the BRIC countries that list in the US or Luxembourg without using DRs. Data on listings in the UK comes directly from the London Stock Exchange (LSE). Data on the segment of the LSE called the Alternative Investment Market (LSE AIM), which has been particularly popular among issuers from emerging markets, specifies 
not only the country of incorporation of the foreign issuers, but also the main country of operation. Over 100 companies in their database have main operation in one of the BRIC countries, but are incorporated in the UK or tax havens like the Cayman Islands. As we are interested in the engagement of the corporate sectors in the BRIC countries with foreign stock markets, we include these companies in the sample. This leads us to a total of 549 foreign listings. For each of them, we have: name of the company, host stock exchange, date of foreign listing, location of corporate headquarters (country and city), sector, and value of sales (turnover) for the last year for which data is available (2007 in most cases) obtained from database Orbis, provided by Bureau van Dijk (BvD). It should be noted that fewer than 10 companies have a foreign listing in more than one of the three selected markets. The data can be considered as valid for the end of 2008.

While the dataset described previously is used to study the origin and destinations of foreign listings, to study intermediaries we use a dataset from Citibank documenting all capital raising events between the start of 1990 and end of May 2009, which were conducted with the use of DRs. Not all foreign listings covered in the previous dataset had any capital raising events, since DRs can be issued on the basis of shares already in circulation in the issuer's home market. In contrast, some issuers could have more than one capital-raising event. The virtue of the Citibank database is that for each event it gives the name of the institution sponsoring the issuer (administering the DRs), and the investment bank acting as the lead manager for capital raising. We would not be able to find data on intermediaries for all listings in the core dataset. In total DR issuers from the BRIC countries have 359 capital raising events, out of which at least 311 were conducted on the US, UK or Luxembourg stock market. For 54 issues data on the host market is unavailable, and 5 were conducted on other markets.

In addition to compiling the datasets, we have reviewed the annual reports of stock exchanges in all 7 host and home markets involved for the period of 20002008, as well as the reports of the Bank of New York Mellon, JP Morgan, Citibank, and Deutsche Bank, which as will be discussed are market leaders on the market for DR related services. This has helped us to understand the mechanism of foreign listing, and identify major market trends.

\section{National origins of foreign listed companies}

Table 1 presents basic data on foreign listings at the national level. Out of 549 foreign listings from the BRIC countries, nearly 47\% come from China (including Hong Kong), with Brazil holding the smallest share of $11 \%$. The number of foreign listings more than tripled since the end of 2000, but the growth has been uneven across the four countries. The number of foreign listings has increased by $47 \%$ in India, doubled in Brazil, and increased six-fold in Russia and China. This raises the question of potential existing in the four markets for further foreign listings, which can be assessed by comparing the number of foreign listed firms to the number of all domestically listed firms or the number of large firms. They are large and already listed firms that are most likely to need external equity and have the capacity to access public stock markets. Hong Kong appears 
to be by far the most saturated market. Nearly half of listed firms in Hong Kong are already listed abroad. In contrast, in Brazil, Russia, India, and Mainland China, the potential is big. In each of them the number of firms with more than $€ 200 \mathrm{~m}$ in turnover is at least four times larger than the number of foreign listed firms, and the number of domestically listed firms at least seven times larger. To put it simply, there are thousands of large companies in these markets, which are not listed abroad.

Mainland China seems least penetrated by foreign listings, with the number of firms with turnover exceeding $€ 200 \mathrm{~m}$ six times higher than the number of foreign listings. In India, with over 5,000 domestically listed firms, foreign listings represent a tiny fraction of domestic listings, but on the other hand, India does not seem to have many large and very large companies, resulting in the highest ratio of the number of firms with turnover exceeding $€ 1 \mathrm{bn}$ to the number of foreign listings. For Brazil, in contrast, the latter ratio is the lowest among the BRIC countries.

There is a significant difference between the size of foreign and domestically listed firms. In all countries, issuers that have foreign listings are much larger, but the difference depends on the market. In Hong Kong foreign listed firms are on average $70 \%$ bigger, in Russia twice, in Mainland China four times, in Brazil twelve times, and in India twenty one times bigger than domestically listed firms. Company size is definitely an important factor affecting the propensity of companies to list abroad. Large companies are more likely to need foreign capital, and are more capable to absorb the costs of foreign listing. There are also marked differences in the absolute size of foreign listed firms. While a typical foreign listed firm from Russia or India has just above €80m in turnover, in Mainland China the average is $€ 480 \mathrm{~m}$, and in Brazil €1.6bn. As we will show in the following sections, this is related to the sector structure of foreign listed firm and the features of foreign markets on which they list.

To be sure, the significance of foreign listings in the BRIC countries and their potential to generate future foreign listings cannot be explained solely with basic economic variables such as company size. Other economic and also political factors influence issuers' willingness and ability to list abroad. Hong Kong, for example, experienced the largest numbers of firms seeking foreign listings in the years 1993-1996. Nearly 50\% of all foreign listings from Hong Kong thus took place in the four years leading to the transfer of Hong Kong from the UK to the People's Republic of China. This behaviour of Hong Kong firms can be seen as taking action that may potentially be restricted later, but also as making potential restrictions on foreign listing more difficult to impose. With tens of companies already foreign listed, such restrictions would have caused repercussions in foreign stock markets.

The accelerating flow of issuers to foreign stock markets has caused mixed reactions in the BRIC countries. In China the government can obviously decide on whether to foreign list state-owned enterprises undergoing privatisation. In practice, the China Securities Regulatory Commission (CSRC), which directly controls the stock exchanges in Shanghai and Shenzhen, draws up a list of candidate companies, which is subject to approval by the State Council (Hung et 
al. 2008). With regard to private firms, while the CSRC claims that it promotes foreign listing, in mid-2000s the formalities faced by these companies have become more cumbersome (Ling 2005). The Chinese authorities appear particularly concerned with firms that use tax havens, such as Cayman Islands and Bermuda, for incorporation and later list their shares abroad as non-Chinese companies. Chinese authorities have also been concerned about the imbalance between the demand for and the supply of corporate shares. While demand for domestic stocks in China is high due to high savings rate, popularity of stock market investing among individuals, and severe restrictions on investment in foreign stocks, foreign listing might be seen as limiting the supply, and increasing the likelihood of stock price bubbles. Options being considered include the repatriation of foreign listed firms (including those listed in Hong Kong back to Mainland China) via multiple listings (on both domestic and foreign exchanges), as well as opening the Chinese stock market to foreign issuers.

In 2005 in Russia the financial regulator (at present the Federal Financial Markets Service) expressed their discontent with Russian companies bypassing the law obliging companies to seek a permission of the regulator and list domestically before they list abroad. Firms would set up holding companies abroad (mainly in Cyprus) and then list abroad as non-Russian incorporated companies. In analogy with the Hong Kong case, Russian foreign listings have been interpreted as insurance against domestic political risks. Amendments to securities laws drafted and aimed at closing this 'loophole' were never introduced, however, as they were seen as against international practices. Instead, Russian authorities make plans to facilitate multiple listings. It should be noted that to prevent foreigners from controlling strategic resources Russia maintains limits on the share of a firm's equity that can be listed abroad, which for energy and mining companies are as low as 5\% (Brown-Humes \& Chung 2006).

Brazil and India seem to have taken a more liberal approach to foreign listings, which may be explained by the shortage of domestic capital available for the corporate sector, most severe in the case in India. In Brazil, a large part of the privatisation programme of the 1990s, has been conducted with share issues on the US markets. Recent reforms of financial reporting and corporate governance, however are said to have contributed to an increase in both domestic and foreign investment in equity to the extent to which foreign listing may be needed less than before (Karmel 2006). The national Brazilian stock exchange BOVESPA itself is listed domestically following a successful initial public offering in 2007. No major signs of control over or opposition to foreign listings can be found for India either, where foreign listings seem to be celebrated as business success stories.

Closing the national analysis of the origins of foreign listed firms from the BRIC countries, we should resist the temptation of labelling concerns about the impact of firms' migrations to foreign stock markets on domestic markets as expressions of protectionism and economic nationalism. As noted in the literature review, there is no conclusive research on the net benefits of foreign listings for domestic stock markets. While benefits accruing to foreign listing firms themselves may be clear, there can also be significant costs to domestic 
firms that do not list abroad, and to the domestic stock market as a whole. For this reason, it is important to know who the foreign listing companies are in relation to the rest of the domestic stock market. This task is undertaken in the following analysis of the sub-national origins of foreign listed companies.

\section{Sub-national origins of foreign listed companies}

Table 2 presents the structure of foreign listings by sector, using the FTSE Dow Jones Industry Classification Benchmark. Two sectors that have enjoyed the highest growth in the number of foreign listings since 2001 are health care and technology, while consumer goods and utilities have recorded the slowest growth. There are also large differences in the average size of foreign listed firms, which can be associated with the economies of scale present in different sectors. The largest foreign listed firms can be found in oil \& gas, followed by basic materials, utilities and telecommunications. By far the smallest are those in the technology sector (including computer services, software and hardware, electronic office and telecommunications equipment, and semiconductors).

Important patterns can be identified by comparing the structure of foreign and domestically listed firms. If the share of a sector in foreign listings is high in relation to its share in domestic listings, we can refer to it as well represented, if it is low - as badly represented. The best-represented sectors in foreign listing are oil \& gas and telecommunications. Each constitutes only approx. 1\% of domestically listed firms, but as much as $6 \%$ or $7 \%$ of foreign listings. Foreign listed firms represent as much as $45 \%$ and $37 \%$ of domestically listed firms in oil \& gas and telecommunications respectively. Basic materials category (the extraction of natural resources other than oil \& gas) is well represented for Brazil and Russia, where it is the most numerous group of foreign listings, but is underrepresented for India and China. Technology firms on the other hand are very well represented for China and particularly India, but not so much for Brazil and Russia. These observations may be explained with the impact of export orientation, and international scope of operations on the propensity to list abroad. Brazil and Russia have internationally established, export-oriented firms in basic materials; China, and particularly India in technology. Such firms may need foreign listings and capital more (to finance international operations) and face lower relative costs (as foreign markets are already familiar with them).

By far the worst represented sector is industrials (including transportation, defense, electrical, and construction industries). There are over thirty times more domestically listed firms in this category than there are foreign listed firms. This pattern holds across the BRIC markets except for Hong Kong. Other sectors with relatively weak representation are consumer goods and consumer services. This differs from country to country, however. They are well represented in Brazil, and particularly badly in Russia and India. This again may be related to the internationalisation of corporate operations. While Brazil has internationally successful consumer goods firms, e.g. in food industry, there are few such firms in Russia or India. 
In summary, there are both similarities and differences in the sector structure of foreign listings across the BRIC countries. Foreign listings tend to concentrate in high-growth, capital intensive sectors, such as technology and telecommunications rather than more stable sectors such as industrials or consumer goods. Thus, a more general feature of stock markets, as particularly suitable to the financing of relatively high-risk and high-return corporate activities, seems to be accentuated in international stock markets (Wójcik 2009b). Foreign listings are also particularly common in sectors with internationally oriented firms, in which the home country has a particular competitive advantage in international markets.

Table 3 shows the structure of the foreign listed firms according to the location of their headquarters. For Brazil and Russia, the results are presented for the two largest cities and the rest of the country; for India and China for the six largest cities and the rest of the country. Hong Kong is not included in this table, but all comparable data for it can be found in table 1 .

The principal finding is a very strong concentration of foreign listed firms in the leading urban centres of each country. In Brazil, Sao Paulo accounts for the majority of foreign listed firms. Every fifth domestically listed firm from Sao Paulo has a foreign listing; in Rio de Janeiro and the rest of the country only every eleventh. In Russia, the dominance of the national financial centre is even stronger. Moscow hosts 58\% of foreign listed firms; every seventh domestically listed firms is foreign listed, while for St Petersburg and the rest of the country only every twentieth.

In China, Beijing is the centre of the market for foreign listings, even though Shenzhen and particularly Shanghai host larger numbers of domestically listed companies. Domestically listed firms from Beijing are nearly twice more likely to be foreign listed than companies from any other major city of the country. Guangzhou, the administrative capital of Guangdong Province, not Shenzhen (also in Guangdong, and the seat of a stock exchange), holds the second highest ratio of foreign to domestically listed firms, along with Shanghai. Chongqing, the commercial centre of Sichuan, does not feature on the map of foreign listings at all (and hardly exists on the map of the domestic stock market).

In India, Mumbai hosts nearly one-third of foreign listed firms. It does not, however, have the highest ratio of foreign to domestically listed firms. Higher ratios are found in Delhi, the political capital of India, as well as in Bangalore, Chennai, and Hyderabad, centres of technology industry. Provincial India, beyond the top six cities, while brimming with domestically listed firms, has little presence on the market for foreign listings.

Could the concentration of foreign listed firms in the largest urban centres be simply due to the concentration of the largest firms in these centres? The table does not give a conclusive answer. While in Brazil and China, there seems to be a positive correlation between the median size of domestically listed firms and the ratio of foreign to domestically listed firms, no such relationship is found in Russia and India. Could this concentration be temporary, whereby firms from the largest urban centres pioneer foreign listing, but with time are followed by firms from other large cities and provinces? Evidence does not support such a 
proposition. Since 2001 foreign listings in Sao Paulo, Moscow, and Beijing have actually grown more rapidly than in the rest of their countries.

While the largest urban centres dominate the market for foreign listings in the BRIC countries, the nature of this dominance depends on the country. In Russia and Brazil, the national financial centre (and the centre of the domestic stock market) overshadows the rest of the country. In China, the leading centre of foreign listing is the political centre of the country, without a stock exchange of its own. In India, centres of technology industry keep up with the financial (Mumbai) and the political (Delhi) capitals of the country. Our findings are consistent with the observation that foreign listing is a much more politically determined process in Mainland China than it is in any of the other BRIC countries. Interestingly, not only Beijing has an advantage over Shanghai, but also Guangzhou - the political centre of Guangdong, has an advantage over its stock exchange hosting neighbour Shenzhen. Foreign listings are a means of corporate expansion, and as such can be attractive to both business leaders and politicians as a way of promoting the local economy. With political control over foreign listing, the political power of places may translate into their presence on the market for foreign listing.

There is another major group of factors that can affect the sub-national geography of foreign listings. After all, even if political authorities may control the process of foreign listing, they do not manage it. Firms embarking on foreign listing need intermediaries that 'take' them to a foreign stock market. It is the nature and structure of these intermediaries to which we will now turn.

\section{Intermediaries in the process of foreign listing}

An absolute majority of foreign listings from the BRIC countries take the form of DRs. To establish a DR program, the issuer develops a team of advisors that typically includes an investment bank, lawyers, accountants, and a depositary bank. Investment bankers advise on the type of DRs and the market on which to launch them, advise on the ratio of DRs to ordinary shares, prepare research reports on the issuer, and promote DRs to investors via meetings and roadshows. If foreign listing involves the issuance of new shares and their offering in the form of DRs in the host market (instead of just a conversion of shares circulating in the home market into DRs), investment bankers advise on the size, pricing and marketing of offering, and underwrite it. As there may be more banks involved in underwriting, the one organising the process is called lead manager. Lawyers prepare contracts between the issuer and other intermediaries, file the required registration statements with the host market regulatory authorities, and manage compliance with the host market laws and regulations. Accountants prepare issuer's financial statements according to the standards required in the host market (JP Morgan 2009).

A depositary bank, also referred to as a sponsor, issues DRs on the basis of issuer's shares held in custody by a custodian bank in the home market of the issuer (appointed by the sponsor), and arranges relationships with market makers and brokers who sell DRs to investors in the host market. A sponsor also 
plays a key role in day-to-day management of a DR program. It maintains a register of DR holders, processes dividend payments for them, and keeps them informed about corporate actions of the issuer (Citibank 2007). The relationship between an issuer and a sponsor is exclusive; an issuer may switch between sponsors, but at any point in time it may have only one sponsor for a DR program. An issuer may choose a different lead manager for each of its offerings.

In this section, we focus on sponsors and lead managers as key intermediaries in foreign listing. We use data on capital raising events (offerings/issues) between the start of 1990 and end of May 2009, which were conducted with the use of DRs by companies incorporated in the BRIC countries. The latter totals 359 and accounts for $35 \%$ of the total number of such events in the world, and $40 \%$ of their value. Data for Hong Kong, with only 3 capital raising events, is aggregated with that of Mainland China.

Table 4 presents sponsors and lead managers by the country of issuer, including a comparison with issuers from a group of four countries (France, Germany, Netherlands, UK), which have the largest number of capital raisings out of all mature markets. Four sponsors cover $100 \%$ of offerings in the sample, with Bank of New York Mellon (BNYM) as a leader in both the BRIC and non-BRIC countries. While in mature markets BNYM and JP Morgan (JPM) sponsor 86\% of the issues, in the BRIC markets BNYM's lead is much weaker, and Citibank (CITI) and Deutsche Bank (DB) appear as equal competitors to JPM. CITI is particularly strong in China and India, and DB in India and Russia. Raw numbers of issues may understate the position of JPM, as it specialises in offerings of large value. This is related to its weak position in India, where both issuers and offerings are typically smaller than in other BRIC markets. In addition, JPM's customer base in the BRIC countries seems to be growing significantly faster than that of its competitors.

The structure of lead managers is much less concentrated than for sponsors. The five investment banks that have managed more than 20 offerings in the BRIC countries since 1990 are (in the order of significance): Merrill Lynch (ML), Credit Suisse (CS), CITI, Morgan Stanley (MS), and Goldman Sachs (GS). Together they were lead managers for $46 \%$ of issues. As the average issue size is very similar across banks, their ranking by value of issues is the same. The ranking of lead managers for mature markets is different (GS, MS, ML, Lehman Brothers, CS). We find some evidence on lead managers' specialisation by country. GS has a big market share in China, but has very weak or no presence in Brazil, Russia, and India. ML also has a big market share in China, but weak presence in Russia. CITI in contrast has a relatively equal presence on all markets. CITI and CS are relative newcomers to the business of lead management. Since the end of 2000, they have managed fifteen and seven times more issues, respectively, than they did between 1990 and 2000. The activities of GS, MS and ML, already established in the 1990s, at best tripled.

Table 5 shows the structure of intermediaries by the sector of issuer. While all sponsors are heavily involved in technology firms, there are strong signs of specialisation. JPM is a leader in oil \& gas, Citibank's focuses on consumer goods and services, DB in financial firms, while BNYM leads in utilities. Specialisation 
seems to apply to lead managers as well. MS leads in oil \& gas and industrials, GS in health care, CS in technology, ML in utilities. CITI has hardly any customers in oil \& gas and industrials, but otherwise covers all sectors.

Finally, table 6 shows the stock markets on which issues intermediated by particular sponsors and lead managers were launched. The majority of issues sponsored by JPM launch at the New York Stock Exchange (NYSE), which is related to the fact that JPM specialises in serving big issuers. For issues sponsored by DB, the London Stock Exchange (LSE) is the main destination, while the Luxembourg Stock Exchange (LUX) gets their foreign issuers mainly via BNYM. Moving to lead managers, ML is by far the most important lead manager for the NYSE, and like GS rarely manages issues launched in Europe. In contrast, CITI and MS are important lead managers for the LSE. There seems to be a significant positive relationship between the median issue value and the share of the top five lead managers. On the LSE, NASDAQ and particularly the NYSE, their share is close to $50 \%$ or higher. On the US OTC markets it is only $30 \%$, and on the LUX almost all issues are managed by investment banks outside of the top 5, with Elara Capital from India in the lead. In other words, big investment banks dominate big issues, with small issues left to smaller firms. It is possible that small issuers simply cannot afford the services of the largest investment banks.

In analogy with the LUX and the OTC markets, the Alternative Investment Market (AIM) segment of the LSE, not covered in table 6, because foreign issuers can list there directly, without DRs, is served mostly by small investment banks. On the AIM they play the role of Nominated Advisors (Nomads) who perform similar functions to lead managers, but on a much smaller scale. In the middle of 2009 127 issuers from the BRIC countries present on the AIM had as many as 43 different Nomads, of which only five had five or more clients. All of the top five Nomads are small investment firms, headquartered in London, and some have offices in the BRIC countries (mostly in China).

To summarise, depositary banking and lead management - services key to foreign listing - are dominated by a handful of institutions - the leading investment banks or in the case of CITI and DB, universal banks with strong investment banking arms, all except DB headquartered in New York. CITI actually acts as both one of the leading sponsors and lead managers (for issues sponsored by CITI, CITI is also the most common lead manager). Institutional concentration is higher in depositary banking than in lead management, most likely due to stronger economies of scale. Both services require relationships and expertise in home and host stock markets, but depositary banking, in addition, involves daily processing of huge amounts of transactions and information (Oxford Metrica 2009). Although the leading intermediaries are all international if not global organisations, they exhibit a degree of specialisation in terms of the size, sector and country of the issuers they service, implying that expertise in the intermediation of foreign listing is specific to particular types of issuers, particular sectors, and countries.

The findings of this section are consistent with those on the sub-national geography of issuers undertaking foreign listings. The WCN literature 
demonstrates that the offices of leading investment banks (and other advanced business services firms) are highly concentrated in the leading urban centres, referred to as world cities. In fact, the geography of world cities corresponds well with the centres of foreign listings identified in table 3. In Brazil and Russia, Sao Paulo and Moscow are by far the largest concentrations of global investment bank offices, overshadowing Rio and St Petersburg in this respect (Rossi \& Taylor 2005; 2006; Gritsai 2004). In China, Beijing is more prominent as a location of such service providers than Shanghai (Taylor et al. 2009). In India, Mumbai's lead in the world city rankings is stronger than in the market for foreign listing, which can probably be explained by the fact that foreign listings from India rely to a greater degree on the services of smaller investment banks, often of Indian origin, with offices in the high-technology centres beyond Mumbai. Thus, in analogy with the geography of domestic listings being driven to a large extent by the location of investment banks and other relevant services firms (Wójcik forthcoming), the propensity of firms to list abroad seems to be influenced by the proximity of their decision making centres to the offices of global investment banks that are instrumental in 'taking' firms to foreign stock markets. In the following section, we will focus on the destination of foreign listings.

\section{Destinations of foreign listings}

Table 7 presents the stock markets on which issuers from the BRIC countries are listed. Overall the US markets (NYSE, NASDAQ and OTC) have attracted almost twice as many issuers as the UK markets, and four times as many as Luxembourg. The Luxembourg Stock Exchange (LUX), though with decades of experience in listing foreign bond issues, holding companies, and investment funds, is a new competitor of the London and New York markets, starting with only one foreign listing from the BRIC countries at the end of 2000. The market that enjoyed the largest growth in the number of new foreign issuers since 2001 is the Alternative Investment Market (AIM) of the LSE (here aggregated with the more recent Professional Securities Market, the latter with very few foreign issuers and similar regulations to the AIM), which was set up in 1995. Destination markets vary greatly by the origin of issuers. Brazilian companies list almost exclusively in the US, Russian companies mainly in the UK. For Indian companies the main destinations are the LUX and the AIM. Chinese companies are spread more evenly across the host markets.

It is not surprising to see New York and London as the main centres of foreign listing. These are by far the leading international financial centres and the largest concentrations of institutional investors, the main buyers of foreign stocks (Z/Yen 2009). The presence of Luxembourg, which has carved out a significant niche in listing Indian (and also Taiwanese) firms, in this company is far from obvious. Beyond its general credentials as an international finance centres, Luxembourg is a major domicile of investment funds with operations in continental Europe. While European Union regulations, which facilitate crossborder equity investment give Luxembourg no particular advantage over 
London, Luxembourg can offer foreign shares quoted in Euro, and information available in French and German.

As table 8 reveals there is a pronounced specialisation of host markets by sector. The Main Market of the LSE specialises in oil \& gas, basic materials, and utilities; the NYSE in telecommunications, and health care. Not surprisingly, NASDAQ has the majority of its foreign listings from the BRIC countries in technology and consumer services sectors (the latter mostly internet-based services). While the LUX may appear to specialise in technology stocks as well, this result is driven rather by its geographical focus on India. There are also big differences in the typical size of foreign issuers. The Main Markets of the LSE, and particularly the NYSE host the largest firms, while NASDAQ, the LUX, and particularly the AIM the smallest. For NASDAQ, this result stems mostly from the fact that technology firms from the BRIC countries are typically small (see table 2).

A number of factors can explain the distribution of the BRIC foreign listings by host market. First of all, host markets differ in terms of direct and indirect costs of foreign listing. The NYSE and the LSE Main are most expensive. The maximum combined listing and annual fee an issuer is charged is capped at the level of approx. $\$ 500$ thousand a year at either exchange, while the corresponding figure for NASDAQ is between $\$ 100$ thousand and $\$ 180$ thousand (depending on the segment of NASDAQ), with costs at the AIM, the LUX, and the US OTC much lower, according to our calculations based on information available on the websites of the exchanges involved. In addition to costs, the NYSE and the LSE Main Market have explicit requirements in terms of issuer's size. For NASDAQ and the LUX such requirements are less stringent, while the AIM and the US OTC have no size requirements.

Indirect costs, concerning reporting and corporate governance requirements, are at least as important as direct ones. Foreign firms listing on the NYSE or NASDAQ have to register with the Securities and Exchange Commission (SEC) and become subject to US securities laws, exposing them to potential lawsuits by investors. They also need to reconcile their financial statements in accordance with the US Generally Accepted Accounting Principles (GAAP). Foreign firm entering the US OTC markets are exempt from the SEC registration. On the Main Market of the LSE foreign firms can list their DRs or ordinary shares. Both have to be admitted to listing by the UK Listing Authority before they are admitted to trading by the LSE. Issuers of ordinary shares also need to prepare their financial reports in accordance with the UK or US GAPP or the International Financial Reporting Standards (IFRS). Listing requirements on the AIM are minimal. The main requirement for a firm to be admitted is that it has the support of a nominated advisor (Doidge et al. 2009). The requirements of the LUX are stricter than those on the AIM but less strict than those on the US exchanges.

The relative stringency of regulation over foreign issuers listing on the US exchanges have been further reinforced in 2002 with the Sarbanes-Oxley Act (SOX), which imposed stricter reporting and corporate governance requirements. Since 2007, they have been subject to the most stringent of the SOX provisions, that on the responsibility of management for internal controls over financial reporting. The extent to which the SOX changed the geography of 
foreign listing destinations is debated. On the one hand it definitely increased the costs of listing on the US exchanges, and may therefore be seen as one explanation of the success enjoyed by the LUX along the AIM in attracting the largest numbers of issuers from the BRIC countries (Piotroski \& Srinivasan 2008). On the other hand, most issuers entering the AIM and the LUX are so small that they would never qualify to be listed on NASDAQ, not to mention the NYSE (Doidge et al. 2009). Alternatively, for some firms listing on host markets with lenient requirements may be a stepping-stone before listing on more regulated markets.

Industrial specialisation of the host market can also explain the destination of foreign listings. Firms are attracted to markets that concentrate other large and leading firms from the same sector, as this is where analysts specialising in the sector are found, and where investors look for companies from the sector to invest in. Presence on such markets is like presence in Paris or Milan in fashion industry. In this vein, listing on NASDAQ, which started as a domestic market, is now seen as an achievement for any technology company worldwide. This also explains why the LSE Main Market hosts a large group of foreign issuers in oil \& gas, basic materials, and utilities, while the NYSE in telecommunications and health care. Their respective domestic markets boast many large companies in these sectors.

Proximity between countries in terms of trade links may also affect the hosthome market pairings. Presence on a host stock market may support a firm's exports by improving its visibility, and exports may make host market investors more familiar with the firm (Sarskissian \& Schill 2004). For Brazilian companies European markets, and for Russian firms US markets are relatively unimportant, which may explain a limited engagement of issuers from these countries with the European and US stock markets respectively. The role of cultural proximity is difficult to prove. If it was crucial, we would expect Hong Kong and Indian firms listing in London rather than the US. In fact, Hong Kong issuers have a very weak presence on the LSE, and Indian firms have been attracted mainly to the LUX.

Stock exchanges should not be treated as immobile fixtures of the host markets. As foreign listing is one of the fastest growing businesses of stock exchanges, they compete with each other by trying to reach issuers in their home countries (Capaldo et al. 2008). In addition to maintaining offices in Hong Kong, the NYSE, NASDAQ and the LSE all set up offices in Beijing between September 2007 and January 2008. In 2004 NASDAQ appointed a Russian-speaking director at their London office (Baibakov 2004). However, stock exchanges themselves are relatively small businesses that have no resources to maintain extensive branch networks abroad, except for outposts in key locations. In contrast to investment banks acting as sponsors or lead managers, with revenues in tens or hundreds of billions of $\$$, revenues of exchanges are counted only in hundreds of millions. They remain destinations of foreign listings rather than key intermediaries. They are large international investment banks that act as spanners between the home and host markets.

What affects the competition for foreign listings is also co-operation between stock exchanges in home and host markets. All the destination exchanges 
considered have been active establishing close relationships with their counterparts in the BRIC countries, signing memoranda of understanding, aimed at facilitating investors' access to each other's markets, and a transfer of stock market know-how. Chinese stock exchanges and regulatory authorities, for example, expressed an interest in co-operation with NASDAQ in order to develop a local stock market for high-growth firms. The LSE has been in talks with the exchange in Hong Kong about establishing simultaneous listing for Chinese firms in Hong Kong and London. The NYSE has acquired 5\% ownership of the National Stock Exchange of India (with Goldman Sachs holding 5\% as well), and 1\% of BOVESPA in Brazil (Kumar \& Kumar 2007). In the future we may expect more ownership links between stock exchanges in the BRIC countries and those in the leading stock market centres in Europe and North America. Foreign listings may also affect consolidation between stock exchanges in Europe and the US. It is interesting to note that in terms of the sectoral composition of foreign listed firms from the BRIC countries, the LSE and NASDAQ complement each other very well, indicating large synergies that could results from a merger.

Financial diplomacy is involved in the competition among stock exchanges for issuers in emerging markets. Former PM Tony Blair added profile to the LSE's activities in China on more than one occasion, e.g. opening their office in Beijing in 2008. In 2007, executives of the LUX participated in the Economic Mission of Luxembourg to India. The significance of foreign listing is also recognised by the authorities of financial centres. The City of London Corporation recently commissioned an international study on the cost of capital, focusing on comparing the cost of raising equity on the LSE with the US and other European exchanges (Oxera 2006). On the other side of the Atlantic, Mayor Bloomberg and Senator Schumer asked McKinsey to work with the New York City Economic Development Corporation to research the measures needed to sustain New York's and the US leadership in global financial services. The report pays a lot of attention to foreign listing and foreign stock issuance migrating away from New York (McKinsey 2007).

\section{Conclusions and implications}

The objective of our paper was to present the economic geography of foreign listing by focusing on companies from Brazil, Russia, India, and China entering the stock markets in the US, UK, and Luxembourg. Having identified the weaknesses of existing literature on foreign listing, we have proposed a combination of the world city network and the geography finance approaches as a conceptual lens through which to study foreign listing from an economic geography perspective. On the empirical front, we have collected a dataset on all issuers from the BRIC countries present on the stock markets in the US, UK, and Luxembourg, and a comprehensive dataset on stock issues conducted by these companies. Our analysis has mapped the national origins of the foreign listed companies, their sub-national origins in terms of sectors and cities, major intermediaries involved in the process of foreign listing, as well as the destinations of foreign listings in terms of host stock exchanges, and cities where they are located. 
The main finding of this paper is that foreign listing activity is highly concentrated in world cities. The major institutions organising host markets for foreign listings, including stock exchanges are located in international finance centres, with New York and London in the lead. The dominant intermediaries in the foreign listing process are the leading global investment banks, operating out of these cities as well. Finally, issuers listing their shares abroad come mainly from the leading economic centres of their respective home countries. Details differ between countries and between sectors, but the pattern holds - foreign listing is part of the world city network. What is more, if foreign listing benefits foreign listed firms but disadvantages domestic firms, then the highly uneven spatial distribution of foreign listings within their home countries implies the concentration of the benefits of foreign listing in leading urban centres, and the concentration of costs in other cities and provincial areas. Thus, foreign listing may contribute to the concentration of financial and corporate power in world cities, and can be seen as a factor of world city formation. In this sense, foreign listing pits New York against London, New York against Sao Paulo, but also Sao Paulo against Rio de Janeiro.

While the foreign listing market is embedded within the world city network, it differs significantly between the BRIC countries. In Brazil, foreign listing is mostly about very large companies headquartered in Sao Paulo listing in New York, representing mostly such industries as basic materials, utilities, and consumer goods and services. They seem to face few political barriers in the process. In Russia, Moscow based companies active in basic materials, oil \& gas industries list mostly in London. The process is politically sensitive as the Russian authorities try to prevent foreign control over strategic industries, and see foreign listing as a threat to the future of Moscow as international financial centre. The most typical Indian companies seeking foreign listings are relatively small technology firms, not only from Mumbai or Delhi but also from the technology clusters of Hyderabad, Bangalore and Chennai. More often than in the case of other BRIC countries, they are assisted in the process by relatively small, domestic investment banks, and list mainly on London's AIM and in Luxembourg. Finally, Chinese foreign listing firms are mostly large companies, coming from a variety of sectors, with industrials and financials in the lead, and spread quite evenly between the London and New York markets. Beijing dominates Shanghai as the headquarter location of foreign listed firms. China has the largest population of foreign listed firms in the world, but also the largest potential for further growth in their number. Considering the abundance of domestic savings in China, the future decisions of the Chinese authorities with regard to foreign listing and the opening of the domestic stock market to foreign investors and issuers will have crucial consequences for the global foreign listing market and the geography of financial centres.

Our paper uses and supports the literature on the world city network, but is not uncritical of it. We would argue that the analysis of the networks of advanced business services and their restructuring can only give partial answers about the future of cities and the world economy. It is crucial in our view to study the interaction with and the impact of these service firms on the corporate sector as a whole. Here come the benefits of marrying the world city network with the geography of finance approach, studying the relations between financial markets 
and corporate sector. However, we are not uncritical of the geography of finance perspective either. The latter focuses on institutional investors as major actors on international financial markets. This paper, in turn, reminds us of the salience of investment banks as key to understanding the economic geography of finance.

There are limits to how much a largely quantitative exploratory study can tell us about the nature of foreign listing. Case studies of foreign listing, including a detailed coverage of the interaction between issuers and intermediaries, as well as the role of investors' demands, would be one obvious direction for further research. To the best of our knowledge, there are no such case studies available in the academic literature concerning foreign listing from emerging markets. The range of intermediaries relevant to foreign listing should also be extended beyond investment banks. It is possible, for example, that venture capital firms influence foreign listing decisions of high-technology firms.

The financial crisis that started in 2008 has a great potential to reshuffle the world of foreign listing. With a drought of capital available for corporations on equity markets in North America and Europe, stock markets in the BRIC countries and other emerging markets may for the first time have a chance of attracting foreign issuers to their own financial centres. Second, the geography of investment banks seems to be changing for good. Their reputation, particularly for the US banks, is severely damaged, and many had to cede controlling stakes in their organisations to Asian financial firms. This may imply more control by the institutions in the BRIC countries and other emerging markets over the market for foreign listing, and possibly more politicisation of the process. One way or another, foreign listing is likely to remain an important factor influencing the map of the world economy.

\section{References}

Baibakov, A. 2004. NASDAQ to attract Russian clients by native language. Komersant, June 23: 6.

Brown- Humes, C., and Chung, J. 2006. Russian watchdog acts to stop companies from listing abroad. The Financial Times, 9 February: 17.

BNYM (Bank of New York Mellon). 2008. Depositary receipts: The Year in review 2008. www.adrbnymellon.com/dr_pub_statistics.jsp accessed on 25 June 2009.

BNYM (Bank of New York Mellon). 2007. The depositary receipts markets: The Year in review 2007. www.adrbnymellon.com/dr_pub_statistics.jsp accessed on 25 June 2009.

Capaldo, A., Härle, P., and Marrs, A. 2008. What's next for exchanges. The McKinsey Quarterly (Financial Services) March. www.mckinseyquarterly.com accessed on 25 June 2009.

Cassis, Y. 2006. Capitals of Capital: A History of International Financial Centres 1780-2005. Cambridge: Cambridge University Press. 
Chandar, N., Patro, D.K., and Yezegel, A. 2009. Crises, contagion and cross-listings. Journal of Banking and Finance forthcoming.

Citibank. 2007. The role of depositary bank: A resource for issuers in the US and global securities markets. wwss.citissb.com/adr accessed on 25 June 2009.

Clark, G.L. and Wójcik, D. 2007. The Geography of Finance: Corporate Governance in a Global Marketplace. Oxford: Oxford University Press.

Doidge, C., Karolyi, G.A., and Stulz, R.M. 2009. Has New York become less competitive than London in global markets? Evaluating foreign listing choices over time. Journal of Financial Economics 91: 253-77.

Doidge, C., Karolyi, G.A., and Stulz, R.M. 2004. Why are foreign firms that are listed in the US worth more? Journal of Financial Economics 71: 205-38.

Edison, H.J., and Warnock, F.E. 2008. Cross-border listings, capital controls, and equity flows to emerging markets. Journal of International Money and Finance 27: 1013-27.

Fernandes, N. 2009. Market liberalizations at the firm level: Spillovers from ADRs and implications for local markets. Journal of International Money and Finance 28: 293-321.

Fernandes, N., and Giannetti, M. 2009. On the fortunes of stock exchanges and their reversals: Evidence from foreign listings. www.ssrn.com accessed on 25 June 2009.

Gritsai, 0. 2004. Global business services in Moscow: Patterns of involvement. Urban Studies 41: 2001-24.

Hung, M., Wong, T.J., and Zhang, T. 2008. Political relations and overseas stock exchange listing: Evidence from Chinese state-owned enterprises. www.ssrn.com accessed on 25 June 2009.

JP Morgan. 2009. Depositary receipts: Reference guide. www.adr.com/Reference/Reference.aspx accessed on 25 June 2009.

Karmel, R.S. 2006. The Brazilian securities market: Brazil finds favour among foreign securities investors. New Jersey Law Journal, 13 November: 23.

Karolyi, G.A. 2006. The world of cross-listings and cross-listings of the world: Challenging conventional wisdom. Review of Finance 10: 99-152.

Karolyi. G.A. 2004. The role of American Depositary Receipts in the development of emerging equity markets. Review of Economics and Statistics 86: 670-90.

Kumar, V.P., and Kumar, J.S. 2007. Bombay Stock Exchange sells 5\% to Singapore Exchange. Dow Jones International News, 7 March. www.djnewswires.com accessed on 25 June 2009.

Ling, T.H. 2005. Chinese firms face overseas listing blues. Business Times Singapore, 3 May: 4. 
McKinsey. 2007. Sustaining New York's and the US' global financial services leadership. www.nyc.gov:80/html/om/pdf/ny_report_final.pdf accessed on 25 June 2009.

Moel, A., Rigobon, R., and G.A. Karolyi. 2001. The role of American Depositary Receipts in the development of emerging markets. Economia 2: 209-73.

Oxera. 2006. The cost of capital: An international comparison. www.oxera.com accessed on 25 June 2009.

Oxford Metrica. 2009. Depositary receipts: Investing in a world asset class. www.adrbnymellon.com/files/OxfordMetrica.pdf accessed on 25 June 2009.

Pagano, M., Roell, A.A., and Zechner, J. 2002. The geography of equity listing: Why do companies list abroad? Journal of Finance 57: 2651-94.

Piotroski, J.D., and Srinivasan, S. 2008. Regulation and bonding: The SarbanesOxley Act and the flow of international listings. Journal of Accounting Research 46: 383-425.

Research Republic. 2008. The future of Asian financial centres - Challenges and opportunities for the City of London.

www.cityoflondon.gov.uk/Corporation/LGNL_Services/Business/Business_supp ort_and_advice/Economic_information_and_analysis/Research_publications/ accessed on 25 June 2009.

Rossi, E.C., and Taylor, P.J. 2006. 'Gateway Cities' in economic globalization: How banks are using Brazilian cities. Tijdschrift voor Economische en Sociale Geografie 97: 515-34.

Rossi, E.C., and Taylor, P.J. 2005. Banking networks across Brazilian cities: Interlocking cities within and beyond Brazil. Cities 22: 381-93.

Sarkissian, S., and Schill. 2009. Cross listing waves and the search for value gains. www.ssrn.com accessed on 25 June 2009.

Sarkissian, S., and Schill. 2004. The overseas listing decision: New evidence of proximity preference. Review of Financial Studies 17: 769-809.

Sassen, S. 2001. The Global City: New York, London, Tokyo. Princeton: Princeton University Press.

Stulz, R.M. 1999. Globalization, corporate finance, and the cost of capital. Journal of Applied Corporate Finance 12: 8-25.

Taylor, P.J. 2004. World City Network: A Global Urban Analysis. London and New York: Routledge.

Taylor, P.J., Ni, P., Derudder, B., Hoyler, M., Huang, J., Lu, F., Pain, K., Wiltox, F., Yang, X., Bassens, D., and Shen, W. 2009. The way we were: Command and control centres in the global space-economy on the eve of the 2008 geoeconomic transition. Environment and Planning A 41: 7-12. 
Wójcik, D. 2009. Financial centre bias in primary equity markets. Cambridge Journal of Regions, Economy and Society forthcoming.

Wójcik, D. 2009b. Innovation and stock markets: International evidence on manufacturing and services. www.ssrn.com accessed on 25 June 2009.

Wójcik, D. 2006. Convergence in corporate governance: Evidence from Europe and the challenge for economic geography. Journal of Economic Geography 6: 639-660.

Z/Yen. 2009. Global Financial Centre Index-5. www.zyen.com/Activities/Online_surveys/GFCI.htm accessed on 25 June 2009. 


\begin{tabular}{|c|c|c|c|c|c|c|}
\hline & Brazil & Russia & India & China & $\begin{array}{l}\text { Hong } \\
\text { Kong }\end{array}$ & Total \\
\hline No. of foreign listed (FL) firms & 60 & 94 & 138 & 154 & 103 & 549 \\
\hline$\%$ growth in FL since the end of 2000 & 100 & 492 & 47 & 500 & 248 & 212 \\
\hline Median turnover (t/o) of FL firms (m $€$ ) & 1,558 & 81 & 85 & 479 & 175 & 162 \\
\hline Median turnover $(\mathrm{t} / \mathrm{o})$ of $\mathrm{DL}$ firms $(\mathrm{m} €)$ & 123 & 37 & 4 & 113 & 106 & 19 \\
\hline \multicolumn{7}{|l|}{ No. of FL firms as \% of: } \\
\hline No. of domestically listed (DL) firms & 13 & 7 & 3 & 9 & 45 & 6 \\
\hline No. of firms with $\mathrm{t} / \mathrm{o}>50 \mathrm{~m} €$ & 20 & 16 & 15 & 12 & 72 & 17 \\
\hline No. of firms with $\mathrm{t} / \mathrm{o}>200 \mathrm{~m} €$ & 24 & 23 & 24 & 16 & 87 & 24 \\
\hline No. of firms with $\mathrm{t} / \mathrm{o}>1 \mathrm{bn} €$ & 80 & 138 & 194 & 105 & 264 & 137 \\
\hline
\end{tabular}

Source: Authors' calculations based on data from BNYM, LSE, and BvD (also for table 2 and 3)

Tab. 2. The structure of issuers by sector

\begin{tabular}{|c|c|c|c|c|c|c|c|c|c|c|c|c|c|c|c|}
\hline \multirow[b]{2}{*}{ Sector } & \multicolumn{6}{|c|}{$\%$ of foreign listed (FL) } & \multicolumn{6}{|c|}{$\%$ of domestically listed (DL) } & \multirow{2}{*}{$\begin{array}{l}\text { FL as } \\
\% \text { of } \\
\text { DL }\end{array}$} & \multirow{2}{*}{$\begin{array}{l}\% \text { growth in } \\
\text { FL since the } \\
\text { end of } 2000\end{array}$} & \multirow{2}{*}{$\begin{array}{c}\text { Median } \\
\text { turnover of FL } \\
\text { firms }(m €)\end{array}$} \\
\hline & $\mathrm{B}$ & $\mathrm{R}$ & 1 & C & $\mathrm{HK}$ & Total & $\mathrm{B}$ & $\mathrm{R}$ & 1 & C & $\mathrm{HK}$ & Total & & & \\
\hline Basic Materials & 25 & 24 & 6 & 10 & 0 & 11 & 7 & 11 & 11 & 13 & 1 & 11 & 6 & 239 & 1,811 \\
\hline Consumer Goods & 17 & 4 & 12 & 9 & 17 & 11 & 13 & 11 & 17 & 12 & 6 & 15 & 5 & 138 & 145 \\
\hline Consumer Services & 12 & 5 & 8 & 11 & 14 & 10 & 10 & 8 & 12 & 12 & 21 & 12 & 5 & 184 & 229 \\
\hline Financials & 10 & 10 & 19 & 16 & 20 & 16 & 30 & 13 & 15 & 6 & 42 & 14 & 7 & 219 & 314 \\
\hline Health Care & 0 & 1 & 4 & 8 & 1 & 4 & 1 & 2 & 5 & 7 & 1 & 5 & 5 & 900 & 162 \\
\hline Industrials & 5 & 9 & 17 & 18 & 26 & 16 & 22 & 43 & 30 & 34 & 15 & 32 & 3 & 214 & 367 \\
\hline Oil \& Gas & 2 & 18 & 5 & 5 & 0 & 6 & 1 & 1 & 1 & 1 & 0 & 1 & 45 & 220 & 4,359 \\
\hline Technology & 0 & 1 & 20 & 16 & 12 & 12 & 1 & 1 & 7 & 11 & 7 & 6 & 12 & 371 & 38 \\
\hline Telecommunications & 12 & 15 & 5 & 5 & 6 & 7 & 5 & 2 & 1 & 1 & 3 & 1 & 37 & 193 & 897 \\
\hline Utilities & 18 & 13 & 4 & 4 & 4 & 7 & 10 & 10 & 1 & 4 & 4 & 3 & 14 & 117 & 918 \\
\hline Total (\%) & 100 & 100 & 100 & 100 & 100 & 100 & 100 & 100 & 100 & 100 & 100 & 100 & 6 & 212 & 396 \\
\hline
\end{tabular}


Tab. 3. Issuers by city

\begin{tabular}{|c|c|c|c|c|c|c|}
\hline $\begin{array}{l}\text { City / Rest of } \\
\text { country }\end{array}$ & $\begin{array}{c}\% \text { of } \\
\text { foreign } \\
\text { listed }(F L)\end{array}$ & $\begin{array}{c}\% \text { of } \\
\text { domestically } \\
\text { listed (DL) }\end{array}$ & $\begin{array}{c}\text { Median } \\
\text { turnover of } \\
\mathrm{FL}(\mathrm{m} €)\end{array}$ & $\begin{array}{c}\text { Median } \\
\text { turnover of } \\
\text { DL }(m €)\end{array}$ & $\begin{array}{c}\mathrm{FL} \text { as } \% \text { of } \\
\mathrm{DL}\end{array}$ & $\begin{array}{l}\% \text { growth in } \mathrm{FL} \\
\text { since the end of } \\
2000\end{array}$ \\
\hline Sao Paulo & 54 & 28 & 1,319 & 201 & 20 & 93 \\
\hline Rio de Janeiro & 15 & 9 & 4,688 & 35 & 9 & 100 \\
\hline Rest of Brazil & 31 & 63 & 1,543 & 125 & 9 & 70 \\
\hline Moscow & 58 & 45 & 1,101 & 35 & 14 & 273 \\
\hline St Petersburg & 4 & 5 & 493 & 39 & 5 & no FL before 2001 \\
\hline Rest of Russia & 38 & 49 & 503 & 44 & 5 & 93 \\
\hline Mumbai & 31 & 16 & 141 & 7 & 4 & 289 \\
\hline Delhi & 17 & 15 & 102 & 13 & 5 & 280 \\
\hline Kolkata & 8 & 5 & 151 & 12 & 4 & 350 \\
\hline Bangalore & 5 & 3 & 145 & 20 & 5 & 200 \\
\hline Hyderabad & 10 & 2 & 81 & 8 & 7 & no FL before 2001 \\
\hline Chennai & 11 & 4 & 31 & 13 & 6 & 300 \\
\hline Rest of India & 18 & 54 & 44 & 5 & 1 & 900 \\
\hline Beijing & 33 & 3 & 75 & 198 & 22 & 560 \\
\hline Shanghai & 20 & 6 & 106 & 143 & 13 & 150 \\
\hline Shenzhen & 9 & 4 & 78 & 78 & 9 & 350 \\
\hline Chongqing & 0 & 1 & 0 & 86 & 0 & no FL \\
\hline Tianjin & 1 & 3 & 2,251 & 90 & 4 & no FL before 2001 \\
\hline Guangzhou & 4 & 2 & 375 & 170 & 13 & 100 \\
\hline Rest of M.China & 34 & 81 & 333 & 109 & 7 & 325 \\
\hline
\end{tabular}


Tab. 4. Sponsors and lead managers by the country of issuer

\begin{tabular}{|c|c|c|c|c|c|c|c|c|}
\hline & Brazil & Russia & India & China & BRIC & $\begin{array}{l}\text { Non- } \\
\text { BRIC }\end{array}$ & $\begin{array}{l}\% \text { growth } \\
\text { in the no. } \\
\text { of issues } \\
\text { since end- } \\
2000\end{array}$ & $\begin{array}{c}\text { Median } \\
\text { issue value } \\
(\mathrm{m} €)\end{array}$ \\
\hline Bank of New York (BNYM) & 55 & 54 & 48 & 43 & 48 & 67 & 223 & 64 \\
\hline Citibank (CITI) & 11 & 2 & 21 & 24 & 18 & 5 & 210 & 60 \\
\hline Deutsche Bank (DB) & 0 & 29 & 24 & 6 & 16 & 9 & 222 & 75 \\
\hline JP Morgan (JPM) & 34 & 15 & 6 & 27 & 17 & 19 & 510 & 151 \\
\hline All sponsors & 100 & 100 & 100 & 100 & 100 & 100 & 250 & 70 \\
\hline Citigroup (CITI) & 9 & 10 & 9 & 7 & 8 & 3 & 1,400 & 70 \\
\hline Credit Suisse (CS) & 19 & 10 & 2 & 19 & 10 & 4 & 640 & 140 \\
\hline Goldman Sachs (GS) & 0 & 2 & 4 & 14 & 6 & 15 & 210 & 188 \\
\hline Merrill Lynch (ML) & 19 & 2 & 12 & 16 & 13 & 11 & 200 & 113 \\
\hline Morgan Stanley (MS) & 9 & 12 & 4 & 12 & 8 & 15 & 140 & 142 \\
\hline Other & 45 & 63 & 69 & 32 & 54 & 53 & 220 & 39 \\
\hline All lead managers & 100 & 100 & 100 & 100 & 100 & 100 & 250 & 70 \\
\hline No. of issues & 47 & 41 & 162 & 109 & 359 & 116 & NA & NA \\
\hline Median issue value ( $\mathrm{m} €$ ) & 101 & 300 & 39 & 100 & 70 & 107 & NA & NA \\
\hline
\end{tabular}

Note: \% growth in the no. of issues and average issue value per institution apply to BRIC issuers only

Source: Authors' calculations based on data from Citibank (also for table 5 and 6 ) 
Tab. 5. Sponsors and lead managers by the sector of issuer

\begin{tabular}{|c|c|c|c|c|c|c|c|c|c|c|c|c|}
\hline & \multicolumn{4}{|c|}{ Sponsors } & \multicolumn{6}{|c|}{ Lead managers } & \multirow{2}{*}{$\begin{array}{l}\text { No. of } \\
\text { issues }\end{array}$} & \multirow{2}{*}{$\%$} \\
\hline & BNYM & CITI & DB & JPM & CITI & CS & GS & $\mathrm{ML}$ & MS & Other & & \\
\hline Basic Materials & 13 & 12 & 9 & 11 & 13 & 13 & 4 & 11 & 14 & 12 & 42 & 12 \\
\hline Consumer Goods & 12 & 18 & 12 & 2 & 10 & 13 & 4 & 13 & 0 & 13 & 40 & 11 \\
\hline Consumer Services & 12 & 15 & 10 & 3 & 10 & 13 & 17 & 11 & 10 & 9 & 38 & 11 \\
\hline Financials & 9 & 8 & 17 & 13 & 23 & 11 & 9 & 17 & 3 & 8 & 38 & 11 \\
\hline Health Care & 6 & 8 & 3 & 13 & 10 & 5 & 22 & 7 & 0 & 7 & 26 & 7 \\
\hline Industrials & 9 & 11 & 10 & 10 & 3 & 8 & 4 & 4 & 17 & 12 & 36 & 10 \\
\hline Oil \& Gas & 3 & 2 & 2 & 13 & 0 & 3 & 4 & 4 & 14 & 4 & 15 & 4 \\
\hline Technology & 20 & 17 & 29 & 26 & 17 & 29 & 17 & 22 & 21 & 22 & 78 & 22 \\
\hline Telecommunications & 6 & 9 & 3 & 3 & 10 & 3 & 9 & 0 & 17 & 5 & 21 & 6 \\
\hline Utilities & 11 & 2 & 3 & 5 & 3 & 3 & 9 & 11 & 3 & 8 & 25 & 7 \\
\hline All sectors (\%) & 100 & 100 & 100 & 100 & 100 & 100 & 100 & 100 & 100 & 100 & 359 & 100 \\
\hline
\end{tabular}

Tab. 6. Sponsors and lead managers by host market

\begin{tabular}{|c|c|c|c|c|c|c|c|c|c|c|c|c|}
\hline & \multicolumn{4}{|c|}{ Sponsors } & \multicolumn{6}{|c|}{ Lead managers } & \multirow{2}{*}{$\begin{array}{l}\text { No. of } \\
\text { issues }\end{array}$} & \multirow{2}{*}{$\begin{array}{c}\text { Average } \\
\text { issue value } \\
(\mathrm{m} €)\end{array}$} \\
\hline & BNYM & CITI & DB & JPM & CITI & CS & GS & ML & MS & Other & & \\
\hline LSE & 19 & 6 & 14 & 7 & 7 & 4 & 1 & 3 & 7 & 24 & 46 & 270 \\
\hline LUX & 23 & 1 & 4 & 1 & 2 & & 1 & & & 27 & 30 & 15 \\
\hline NASDAQ & 19 & 18 & 5 & 13 & 5 & 10 & 7 & 7 & 6 & 20 & 55 & 85 \\
\hline NYSE & 39 & 10 & 12 & 32 & 5 & 16 & 10 & 27 & 12 & 23 & 93 & 175 \\
\hline OTC & 41 & 19 & 9 & 7 & 6 & 6 & 4 & 7 & 2 & 51 & 76 & 42 \\
\hline Other & 2 & 2 & 1 & & & & & & & 5 & 5 & 14 \\
\hline Unavailable & 30 & 10 & 13 & 1 & 5 & 2 & & 2 & 2 & 43 & 54 & 20 \\
\hline Grand Total & 173 & 66 & 58 & 61 & 30 & 38 & 23 & 46 & 29 & 193 & 359 & 70 \\
\hline
\end{tabular}


Tab. 7. Issuers by host and home market

\begin{tabular}{lrrrrrr}
\hline & LSE Main & LSE AIM\&P & Luxembourg & NYSE & NASDAQ & US OTC \\
\hline Brazil & 0 & 6 & 0 & 30 & 1 & 23 \\
Russia & 26 & 23 & 0 & 5 & 0 & 40 \\
India & 9 & 45 & 68 & 11 & 3 & 2 \\
China & 6 & 53 & 0 & 36 & 30 & 29 \\
Hong Kong & 1 & 6 & 1 & 5 & 5 & 85 \\
Total & 42 & 133 & 69 & 87 & 39 & 179 \\
\% growth since & 180 & 923 & 6,800 & 190 & 550 & 61 \\
the end of 2000 & & & & & & \\
\hline
\end{tabular}

Source: Authors' calculations based on data from BNYM and LSE

Tab. 8. The structure of issuers by sector and host market

\begin{tabular}{|c|c|c|c|c|c|c|c|}
\hline & $\begin{array}{l}\text { LSE } \\
\text { Main }\end{array}$ & $\begin{array}{c}\text { LSE } \\
\text { AIM\&P }\end{array}$ & Luxembourg & NYSE & NASDAQ & US OTC & Total \\
\hline Basic materials & 21 & 17 & 7 & 14 & 0 & 7 & 11 \\
\hline Consumer goods & 10 & 8 & 16 & 7 & 10 & 15 & 11 \\
\hline Consumer services & 10 & 7 & 6 & 10 & 23 & 11 & 10 \\
\hline Financials & 10 & 28 & 12 & 9 & 3 & 16 & 16 \\
\hline Health care & 2 & 2 & 7 & 7 & 5 & 2 & 4 \\
\hline Industrials & 12 & 18 & 16 & 9 & 10 & 20 & 16 \\
\hline Oil \& gas & 14 & 10 & 4 & 6 & 0 & 3 & 6 \\
\hline Technology & 10 & 5 & 23 & 11 & 38 & 8 & 12 \\
\hline Telecomms & 2 & 2 & 9 & 21 & 10 & 6 & 7 \\
\hline Utilities & 10 & 5 & 0 & 6 & 0 & 13 & 7 \\
\hline Total (\%) & 100 & 100 & 100 & 100 & 100 & 100 & 100 \\
\hline Median turnover ( $m €)$ & 642 & 20 & 52 & 1,710 & 75 & 394 & 396 \\
\hline
\end{tabular}

Source: Authors' calculations based on data from BNYM, LSE and BvD 